\title{
Otomatisasi Pengambilan data Pada Alat Uji Tekan Pasir Cetak WGA Berbasis Arduino Mega 2560 dan Labview
}

\author{
1,2Adhitya Sumardi Sunarya*), 1Dzikri Muhammad Immaduddin \& ${ }^{2}$ Ari Siswanto \\ ${ }^{1}$ politeknik Manufaktur Bandung \\ 2jurusan Teknik Mesin Dan Manufaktur, Program Studi Elektro Mekanik
}

(cooresponding author) adhitya102@yahoo.com*)

\begin{abstract}
Abstrak
Pasir cetak yang digunakan untuk keperluan pengecoran logam sangatlah penting. Pasir cetak digunakan sebagai media cetakan untuk cairan logam. Kekuatan cetakan pasir sebagai media untuk membentuk suatu benda harus di perhatikan karena kekuatan suatu cetakan pasir akan berdampak pada hasil cor. Alat uji tekan pasir di gunakan untuk mengukur kekuatan pasir cetak. Kekuatan tekan pasir cetak yang biasanya digunakan untuk menjadi cetakan pasir harus memiliki gaya sebesar $13,5 \mathrm{~N} / \mathrm{cm} 2-24,5 \mathrm{~N} / \mathrm{cm} 2$, ini berdasarakan data dari buku panduan pengecoran logam. Kekuatan pasir harus mampu menahan gaya dari dalam sekaligus dapat mengeluarkan panasnya cairan logam.
\end{abstract}

Modifikasi yang dilakukan adalah membuat alat uji tekan pasir menjadi otomatis untuk mengoprasikanya dan akuisisi data. Alat ini menggunakan motor DC dan gear reduksi berspesifikasi 2,45Nm dengan shaft hexa untuk menjadi sumber gaya, dan konstruksi ulir trapesium sebagai media mentransimiskan gaya rotasi menjadi gaya translasi. Load cell berspesifikasi $120 \mathrm{Kg}$ dengan eksitasi $2 \mathrm{mv} / \mathrm{v}$ menjadi sensor untuk membaca gaya pada sistem ini. Sensor enkoder dengan spesifikasi 1600 PPR dan IR sensor di gunakan untuk sebagai pengaman. HX711 menjadi rangkaian untuk mengubah data analog to digital pada load cell. BTS7960 sebagai modul pengerak motor DC. Labview menjadi antarmuka untuk sistem pada alat uji tekan pasir WGA. Labview dipilih karena kemudahanya untuk akuisisi data dan program. Ulir trapesium di pilih karena dapat menahan gaya lebih besar di banding ulir jenis lainya. Untuk pembacaan sensor load cell yang sangat fluktuatif, maka di pilih moving average sebagai filter sinyal pada keluaran load cell. Dari hasil uji tekan pasir didapat rata-rata gaya pada alat uji tekan ridsdale 8114 adalah 8,684 N/cm2,dan pada alat uji tekan WGA yang baru adalah $8,7484 \mathrm{~N} / \mathrm{cm} 2$ dengan rata-rata status pengujian NG (not good). Kesalahan presentase adalah 0,74159373 N/cm2.

Kata Kunci: load cell, motor dc, pasir cetak, HX711, BTS7950, labview

\section{Pendahuluan}

\subsection{Latar Belakang}

Alat uji tekan pasir WGA ini adalah pengembangan alat uji tekan pasir dengan penambahan fitur akuisisi data menggunakan mikrokontroler dari penelitian sebelumnya. Alat uji tekan pasir WGA akan mengakuisisi data pembacaan dari sensor load cell yang membaca tekanan gaya. Untuk mengoprasikan alat tersebut dibutuhkan operator untuk memberi gaya dengan cara memutar engkol dan di transmisikan pada poros penggerak. Pada saat engkol di putar poros penggerak akan bergerak maju dan menekan. Kondisi tersebut akan menekan pasir dan menekan sensor untuk membaca berapa besar gaya tekan tersebut.

Alat uji tekan pasir yang digunakan untuk praktikum dan produksi pada laboratorium casting masih menggunakan alat uji tekan konvensional. Cara kerja alat uji tekan konvensional sama dengan cara kerja Alat Uji Tekan WGA, yang membedakan adalah cara pembacaan besarnya gaya yang terbaca. Alat uji tekan konvensional menggunakan manometer untuk membaca tekanan. Posisi terakhir jarum setelah pasir retak atau hancur menunjukan gaya maksimum.

Pembaharuan yang dilakukan adalah dengan mengotomatisasi cara kerja dan pengambilan data. Gerakan poros penggerak akan menekan secar otomatis dan pada saat pasir hancur poros penggerak akan kembali pada posisi semula. Sensor IR dan enkoder berfungsi sebagai pengaman dan untuk mengetahui jarak pada proses penekanan. Mikrokontroler arduino MEGA2560 digunakan sebagai kontroler utama. PC (Personal Computer) dan Labview digunakan sebagai interfce untuk menampilkan grafik perbandingan antara besarnya gaya tekan terhadap jarak. Grafik yang di tampilkan adalah visualisasi tambahan sebagai data yang dibutuhkan untuk casting. Pengukuran gaya tekan menggunakan sensor load cell untuk mempermudah pengukuran.

\subsection{Rumusan Masalah}


Seminar Nasional Instrumentasi, Kontrol dan Otomasi (SNIKO) 2018 Bandung, Indonesia, 10-11 Desember 2018

(ISBN: 978-602-72059-1-8 ; ISSN : 2461-1441)

1.Menciptakan sistem yang otomatis dan antarmuka yang user friendly.

2.Menampilkan data real time antara gaya tekan dan perubahan jarak.

3.Data gaya tekan yang terbaca dapat tersimpan.

4.Kecepatan pergerakan yang konsisten.

\subsection{Batasan Masalah}

1.Pengujian dilakukan pada pasir jenis greendsand (uji tekan).

2.Sensor laod cell yang digunakan dapat menahan beban tidak lebih dari $100 \mathrm{Kg}$.

3. Data yang akan di tampilkan adalah besarnya gaya dan tampilan grafik perbandingan antara gaya dan jarak.

4. Motor DC dengan gearbox digunakan sebagai penggerak.

5. Otomatisasi gerakan motor pada saat menekan dan kembali ke posisi semula.

\subsection{Tujuan}

1. Memodifikasi dan mengembangkan penelitian tedahulu.

2. Menampilkan data yang digital untuk mempercepat pengambilan data praktikum ataupun produksi.

3. Mengetahui posisi sampel pasir akan hancur.

4. Otomatisasi sistem dan pengambilan data.

5. Tekanan yang di berikan dapat menghancurkan pasir dan handal.

6.Kecepatan pergerakan penekanan yang konstan untuk menekan sampel pasir.

\subsection{Manfaat}

1. Gerakan laju penekanan konstan.

2. Ketelitian pembacaan pergerakan lebih presisi.

3.Gaya tekan pada sampel pasir cetak tidak mengalami gaya tambahan. Diskusi

menulis makalah anda. Format (style) yang digunakan dalam dokumen ini sebagai berikut:

untuk Bahasa Indonesia dan 10 kata untuk Bahasa Inggris.

\section{Perancangan dan Diskusi}

\subsection{Alat uji tekan pasir cetak}

alat uji tekan pasir adalah alat untuk menguji kekuatan pasir dengan pengujian tekan. Pengujian ini dimaksudkan untuk mengetahui berapa gaya tekan maksimum yang dapat di terima pasir. Terdapat macam-macam pengujian pasir yaitu uji tekan, uji geser dan uji tarik. Setiap pengujian pasir di uji dengan jenis pasir yang berbeda. Gambar 1 adalah contoh alat uji tekan pasir.

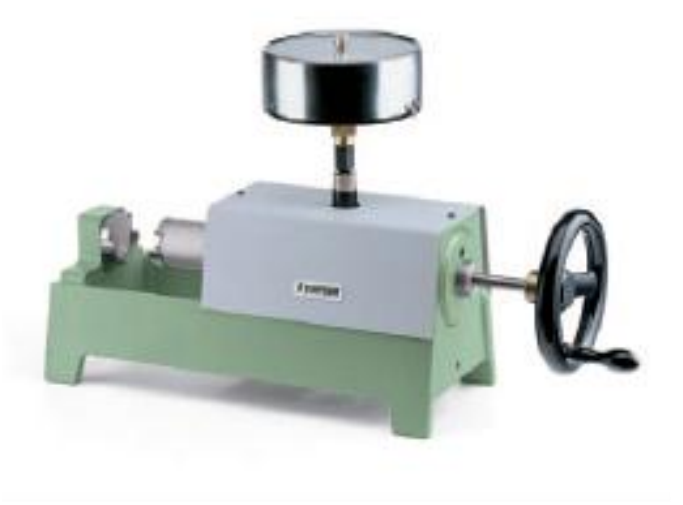

Gambar 1 alat uji tekan pasir cetak.

\section{2 rancangan sistem}

Rancangan sistem di buat otomatis dengan menggunakan beberapa sensor pendukung. Gambaran umum sistem dapat dilihat pada gambar 2.

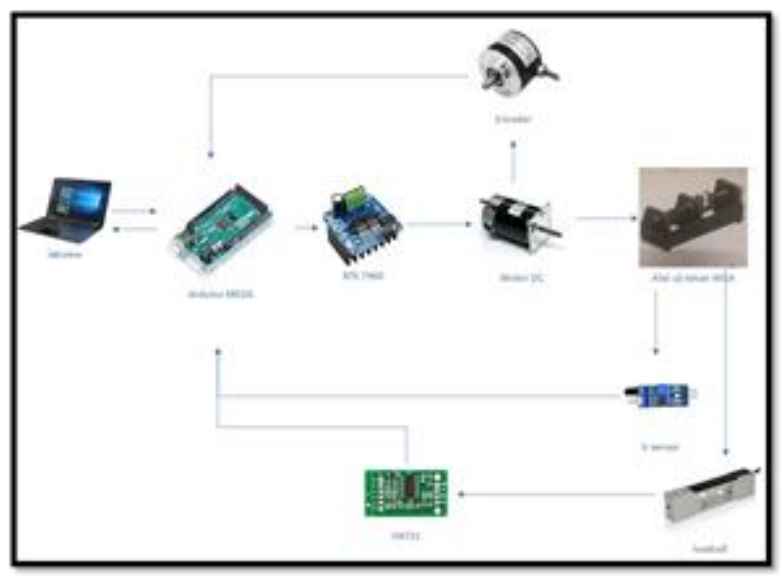

Gambar 2 Gambar Umum Sistem

PC dan Labview digunakan sebagai antarmuka dari alat ini. Arduinomega 2560 sebagai kontrol utama. Sensor loadcell di gunakan sebagai sensor pembaca berat yang selanjutnya di konversi menjadi gaya tekan. Modul hx711 adalah modul 
Seminar Nasional Instrumentasi, Kontrol dan Otomasi (SNIKO) 2018 Bandung, Indonesia, 10-11 Desember 2018

(ISBN: 978-602-72059-1-8 ; ISSN : 2461-1441)

yang berfungsi untuk menguba data analog to digital dan sekaligus sebagai penguat tegangan. Motor dc dan gear reduksi di gunakan supaya putaran motor memiliki torsi besar dan putaran yang pelan. BTS 7960 digunakan sebagai penggerak motor dc. Sensor IR digunakan sebagai pembacaan inisialisasi pisisi homing. Enkoder digunakan untuk mebaca perpindahan dari penampang saat menenkan sampel pasir.

\subsection{Desain Elektrik}

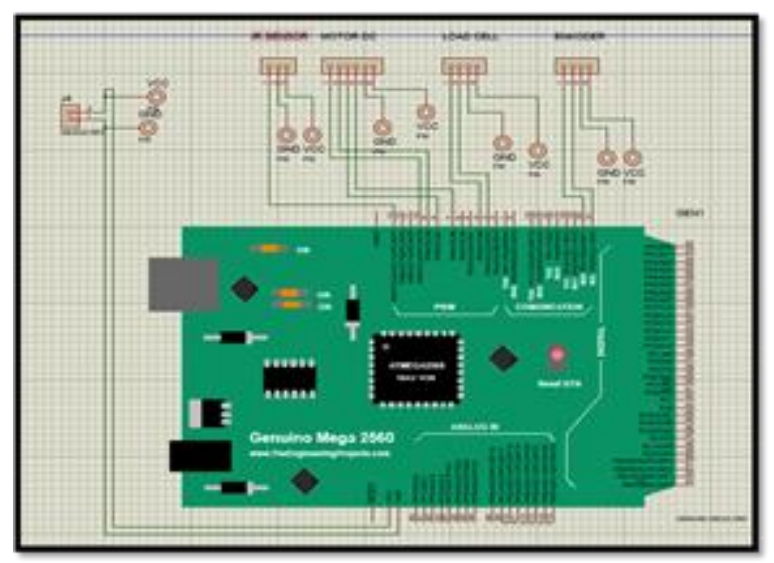

Gambar 2 desain elektrik

Tabel 1 penggunaan pin

\begin{tabular}{|c|c|c|}
\hline No & Komponen & $\begin{array}{c}\text { PIN yang } \\
\text { digunakan }\end{array}$ \\
\hline 1 & $\begin{array}{r}\text { Module penggerak } \\
\text { motor dc }\end{array}$ & $10,9,8,7$ \\
\hline 2 & HX711 & 4,3 \\
\hline 3 & Sensor IR & 13 \\
\hline 4 & Enkoder inkeiment & 20,21 \\
\hline
\end{tabular}

\subsection{Desain Mekanik}

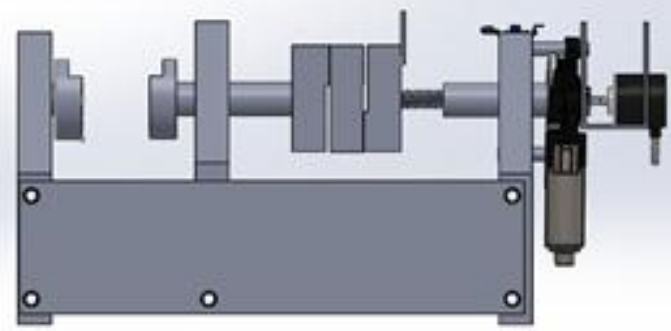

Gambar 3 desain mekanik

Desain mekanik ini merujuk pada alat uji tekan pasir WGA terdahulu dan dilakukan beberapa modifikasi.

Dikarenakan konstruksi alat uji tekan pasir WGA ini menggunakan ulir maka dibawa ini adalah perhitungan untuk mengetahui torsi yang dibutuhkan untuk memutar ulir tersebut.

$\begin{array}{rlll}\mathrm{TL} & = & \text { torsi } & (\mathrm{Nm}) \\ \mathrm{F} & = & \text { gaya dorong sejajar } & (\mathrm{N}) \\ \mathrm{dm} & = & \text { diameter tengah screw } & (\mathrm{m}) \\ \mu & = & \text { koefisien gesek statis } \\ \alpha \quad & \quad \text { sudut pitch } \\ \mathrm{L} & =\quad \text { Panjang pitch } \\ \mathrm{Fges} & = & \text { gaya gesek } & (\mathrm{m}) \\ T_{L}= & F g e s \times \frac{d_{m}\left(\mu \pi d_{m}+L\right)}{2\left(\pi d_{m}-\mu L\right)} \\ & N=\frac{0.18 x 9.8}{\cos 30-0.8 \sin 30}(2)\end{array}$

$N=3.77 N(3)$

$$
\text { Fges }=N \times \mu
$$




$$
\begin{gathered}
\text { Fges }=3.77 \times 0.8 \\
F g e s=3.02(N)
\end{gathered}
$$

$T_{L}$

$$
\begin{array}{r}
=(3.02) \times \frac{\left(13,7 \times 10^{-3}\right)(0.8 \times 3.14 \times(13}{2\left(3.14 \times\left(13,7 \times 10^{-3}\right)\right.} \\
T_{L}=1.016 \times 10^{-5} N m \\
\sigma=F \times A(9)
\end{array}
$$

Karena diameter penampang spesimen adalah 50 $\mathrm{mm}$, maka luas penampang adalah $19,625 \mathrm{~cm}^{2}$.

$$
F=28 \times 19.625(\mathbf{1 0})
$$

$F=549,5 N(11)$

$$
\begin{gathered}
N=\frac{549,5}{\cos 30-0.8 \sin 30}(\mathbf{1 2}) \\
N=1179,18 N(\mathbf{1 3}) \\
T_{L}=(3.02+1179,18) \times \frac{\left(13,7 \times 10^{-3}\right)\left(0.8 \times 3.14 \times\left(13,7 \times 10^{-3}\right)+\left(2.3 \times 10^{-3}\right)\right)}{2\left(3.14 \times\left(13,7 \times 10^{-3}\right)-0.8 \times\left(2.3 \times 10^{-3}\right)\right)}(14) \\
T_{L}=3,977 \times 10^{-3} \mathrm{Nm}(15)
\end{gathered}
$$

Pemilihan komponen tersebut dilakukan dengan cara menyiapkan beberapa pilihan komponen yang cocok dengan fungsinya. Dilakukan perbandingan dan penilaian antara kedua komponen. Komponen yang memiliki nilai tertinggi akan di pilih karena kecocokan dengan sistem. Kolom yang berwarna biru adalah komponen yang dipilih sebagai komponen penunjang dari modifikasi alat uji tekan pasir cetak WGA.

Dari hasil perhitungan di atas maka motor harus dapat berputar dengan torsi $3,977 \times 10^{-3} \mathrm{Nm}$ untuk dapat mendorong spesimen pasir sampai hancur. Spesifikasi motor yang digunakan adalah $25 \mathrm{Kgcm}$, bila satuanya di ubah ke $\mathrm{Nm}$ yaitu 2,45 $\mathrm{Nm}$. Maka motor dengan spesifikasi ini dapat digunakan.

\subsection{5 Pemilihan Komponen}

Tabel 2 pemilihan komponen

\begin{tabular}{|c|c|c|c|c|}
\hline $\mathbf{N}$ & Spesifikasi & \multicolumn{3}{|c|}{ Jenis } \\
\hline & & \multicolumn{3}{|c|}{} \\
\hline 1 & $\begin{array}{c}\text { pengendali } \\
\text { proses }\end{array}$ & PC & $\begin{array}{c}\text { Mikrokontrol } \\
\text { er }\end{array}$ & PLC \\
\hline
\end{tabular}




\subsection{Diagram alir sistem}

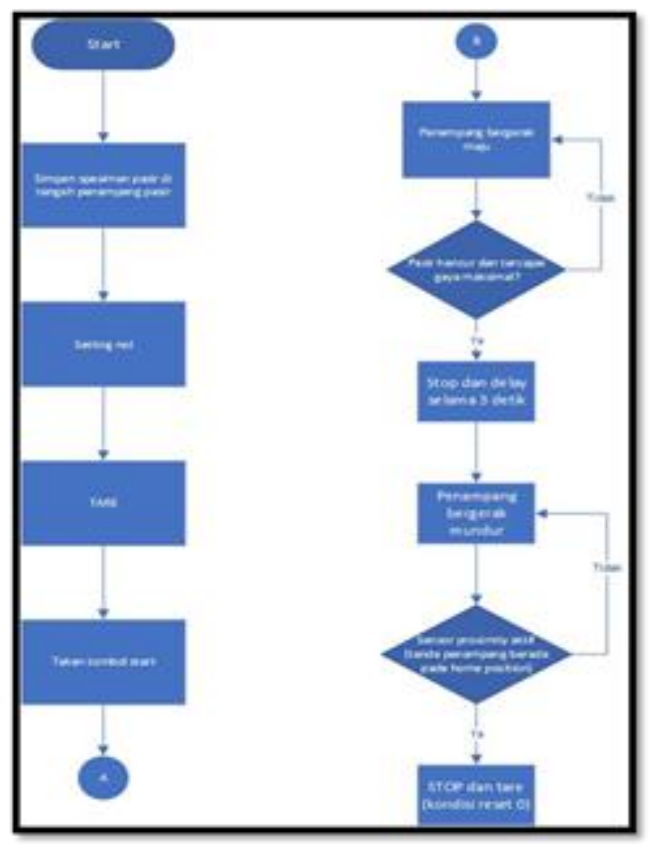

Gambar 4 diagram alir sistem

Diagram alir ini menjelaskan bagaimana sistem ini berfungsi. Dari menyimpan sampel pasir, lalu tekan tombol setting nol dan tare, selanjutnya tekan tombol start. Setelah menekan tombol start makan spesimen pasir akan di tekan sampai hancur dan penampang spesimen berhenti bergerak. Diwaktu yang bersamaan data gaya tekanan maksimum tersimpan pada antarmuka. Setelah 5 detik penampang diam selanjutnya penampang akan kembali ke posisi homing.

\section{Hasil dan diskusi}

\subsection{Pengujian load cell}

Tabel 3 pengujian loadcell

\begin{tabular}{|c|c|c|}
\hline NO & $\begin{array}{c}\text { BERAT BATU } \\
\text { TIMBANGAN(gr) }\end{array}$ & $\begin{array}{c}\text { PENGUKURAN } \\
\text { (gr) }\end{array}$ \\
\hline 1 & 50 & 54 \\
\hline 2 & 100 & 98 \\
\hline 3 & 200 & 198 \\
\hline
\end{tabular}

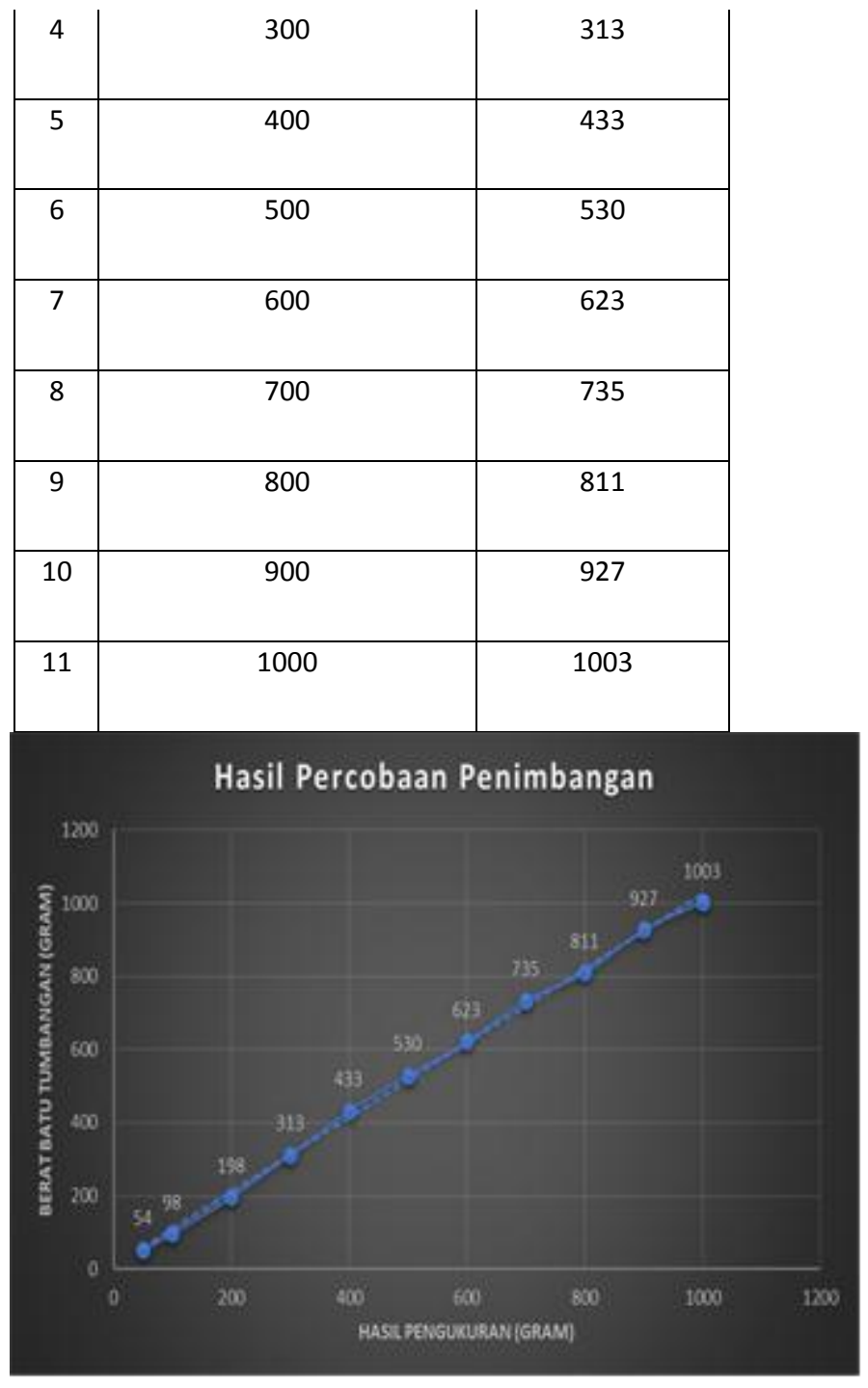

Gambar 5 grafik berat batu timbangan dan pembacaan

\subsection{Pengujian pergerakan}

Tabel 4 pengujian pergerakan

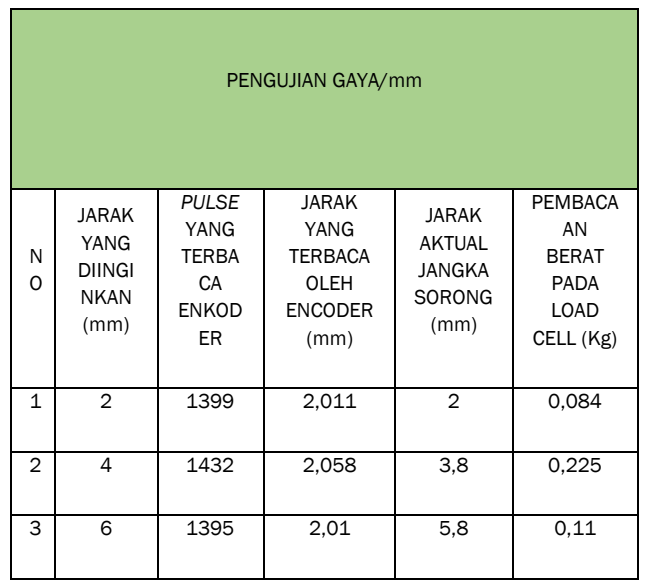




\begin{tabular}{|c|c|c|c|c|c|}
\hline 4 & 8 & 1397 & 2,008 & 7,8 & 0,05 \\
\hline 5 & 10 & 1395 & 2,01 & 9,6 & $-0,014$ \\
\hline 6 & 12 & 1397 & 2,008 & 11,2 & 0,08 \\
\hline 7 & 14 & 1393 & 2,001 & 13 & 0,083 \\
\hline 8 & 16 & 1397 & 2,008 & 15 & 0,138 \\
\hline 9 & 18 & 1395 & 2,01 & 17,1 & 0,071 \\
\hline $\begin{array}{l}1 \\
0\end{array}$ & 20 & 1392 & 2 & 19,1 & 0,11 \\
\hline & RATA & 1399,2 & 2,0145 & & 0,0937 \\
\hline \multicolumn{3}{|c|}{ Error jarak } & \multicolumn{3}{|c|}{$4,50 \%$} \\
\hline \multicolumn{3}{|c|}{ Error berat } & \multicolumn{3}{|c|}{0,0} \\
\hline
\end{tabular}

\subsection{Pengujian penekanan}

Tabel 6 pengujian penekanan

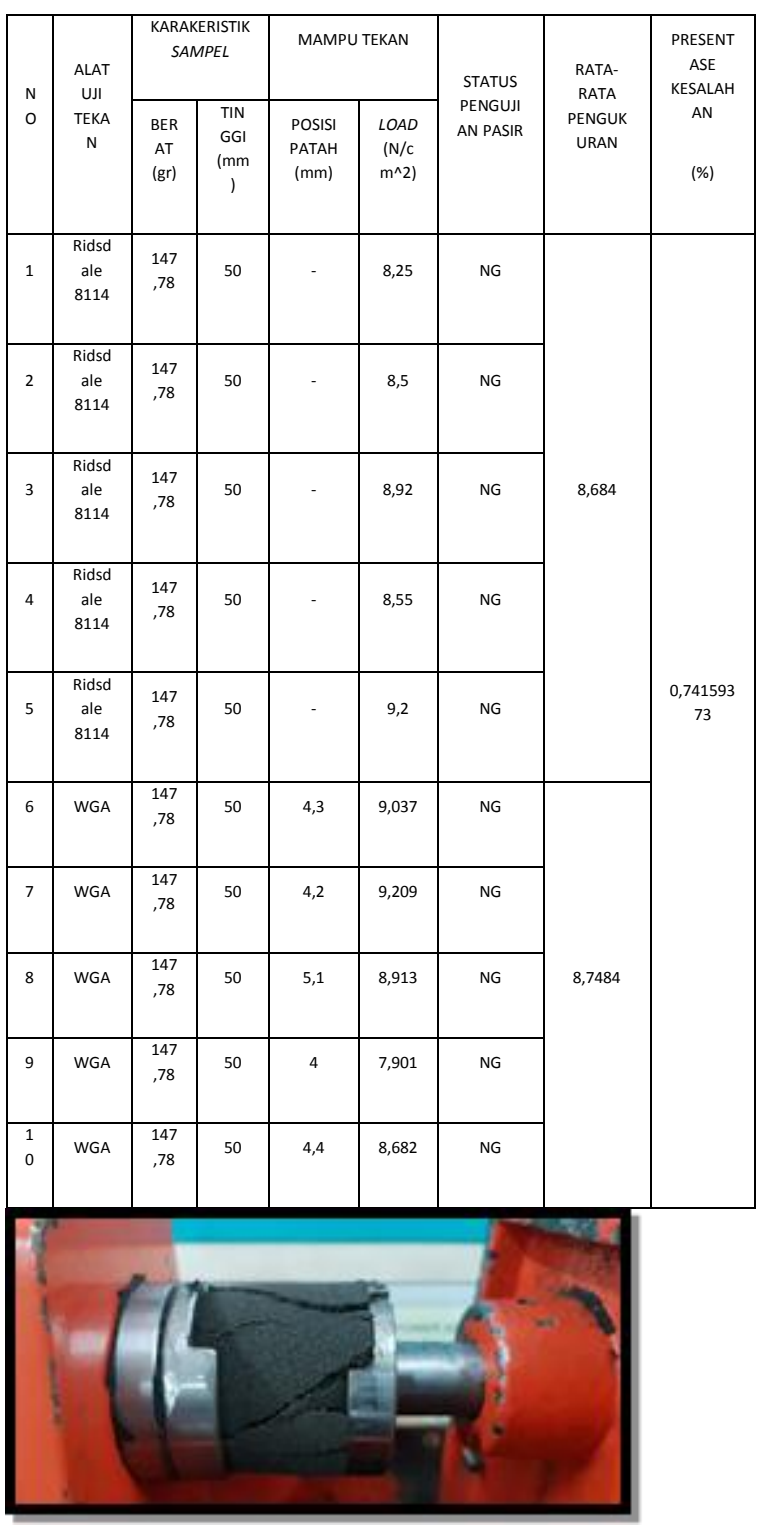

Gambar 6 sampel pasir yang berhasil di tekan

Pengujian pergerakan ini dilakukan untuk melihat apakah ada kesalahan pembacaan dan faktor lain yang mempengaruhi pembacaan. Percobaan dilakukan dengan cara memajukan penampang sejauh $2 \mathrm{~mm}$. Dan di dapat eror jarak sebesar 4,5\% dari dan eror pembacaan berat 0,0837 Kg.

Tabel 5 pengujian kecepatan

\begin{tabular}{|c|c|c|c|}
\hline \multirow{2}{*}{$\begin{array}{l}\mathrm{N} \\
\mathrm{O}\end{array}$} & \multirow[b]{2}{*}{ JARAK } & \multicolumn{2}{|c|}{ WAKTU YANG DI TEMPUH (detik) } \\
\hline & & $\begin{array}{c}\text { PENGUJIAN } \\
\text { WAKTU } \\
\text { TEMPUH } \\
\text { DENGAN } \\
\text { SPESIMEN } \\
\text { PASIR }\end{array}$ & $\begin{array}{c}\text { PENGUJIAN WAKTU } \\
\text { TEMPUH TANPA } \\
\text { SPESIMEN PASIR }\end{array}$ \\
\hline 1 & $10 \mathrm{~mm}$ & 15,5 & 14,3 \\
\hline 2 & $10 \mathrm{~mm}$ & 15,8 & 14,4 \\
\hline 3 & $10 \mathrm{~mm}$ & 15,6 & 14,3 \\
\hline 4 & $10 \mathrm{~mm}$ & 15 & 14,5 \\
\hline 5 & $10 \mathrm{~mm}$ & 15,3 & 14,3 \\
\hline \multicolumn{2}{|c|}{ RATA-RATA } & 15,44 & 14,36 \\
\hline
\end{tabular}

Pengujian kecepatan dilakukan untuk mengetahui apakah pergerakan laju dengan adanya spesimen dan tidak adanya spesimen dapat mempengaruhi kecepatan. 


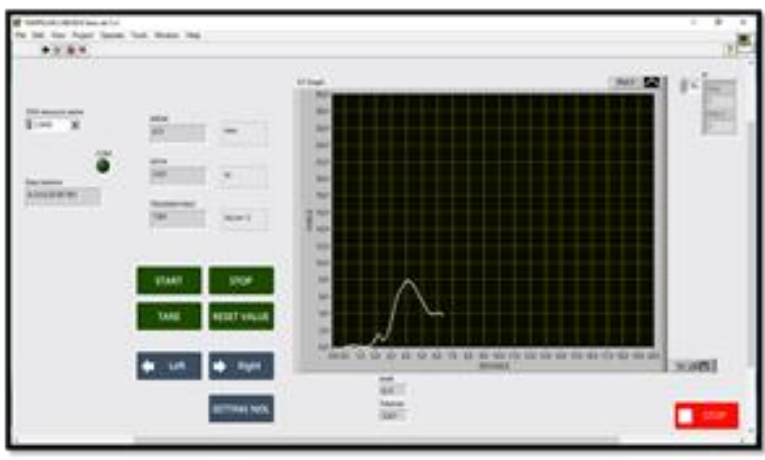

Gambar 7 antar muka hasil penekanan sampel pasir

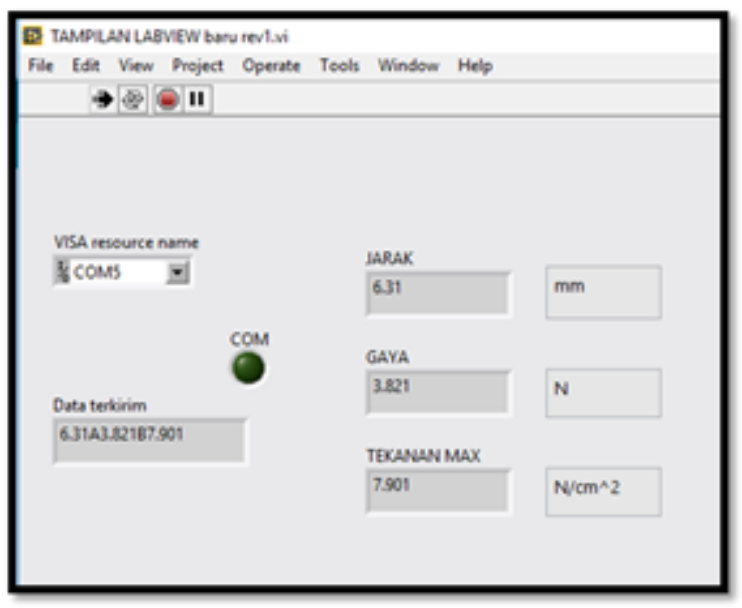

Gambar 8 potongan antar muka

Untuk mengetahui kualitas dari alat uji tekan pasir cetak WGA yang sudah dimodifikasi ini perlu di uji coba. Maka pngujian dilakukan dengan cara membandingkan alat uji tekan pasir WGA dengan alat uji tekan pasir risdale 8114. Hasil dari pengujian dapat dilihat pada tabel 6 .

Pada gambar 6 terlihat bahwa pasir dapat di tekan sampai hancur dan data dapat terbaca. pada tampilan antar muka terlihat grafik penekanan pada gambar 7. Data yang terbaca adalah tekanan maksismum seperti pada gambar 8 dengan jarak perpindahan penampang sejauh $6.31 \mathrm{~mm}$. Dengan sensor enkoder pembacaan jarak lebih presisi.

\section{Kesimpulan}

Berdasarkan pengujian yang dilakukan terhadap sistem yang telah dibangun dapat disimpulkan ke dalam beberapa hal.
1. Sensor load cell dapat diimplementasikan pada sistem penekanan dengan kepresisian pembacaan per 10 gram.

2. Penggunaan sensor enkoder sangat di anjurkan untuk pembacaan gerak dengan kepresisian permili untuk mengetahui dimana pasir akan mendapat gaya tekan maksimum dari penampang.

3. Dengan motor dc dan gear reduksi dengan spesifikasi $12 \mathrm{v}$ dc, 2,45Nm dan shaft hexagonal cukup untuk menekan spesimen pasir sampai hancur.

4. Sistem terkadang tidak berfungsi pada saat setelah melakukan setting nol. Ini dikarenakan antarmuka labview membaca kondisi dimana loadcell membaca data gaya $40 \%$ dari data maksimum gaya yang terbaca.

5. Labview terkadang telat membaca perubahan data yang terbaca arduino. Ini mengakibatkan program tidak dapat berjalan dengan baik.

6. Load cell terkadang membaca data minus (-), yang berarti load cell mendapat gaya tarik bukan tekan. Pada saat load cell membaca data minus maka pembacaan pada antarmuka akan membaca data sebagai nilai 0 .

7. Pergerakan kecepatan penampang pasir lebih lambat saat menekan pasir, tetapi rata-rata kecepatan tersebut realtif sama.

Dari pengujian yang telah dilakukan maka didapat hasil. Beberapa hasil yang didapat tidak sesuai dengan data yang seharusnya. Pasir yang diizinkan untuk digunakan sebagai pasir cetak seharusnya berada pada nilai sekitar 13,5 - 24,5 N/cm2. Maka di dapat faktor yang mempengaruhi data tidak sesuai:

1. Load cell sangat sensitif, karena sensor load cell dipasang pada konstruksi maka bila konstuksi mengalami tekanan dari luar (contoh : base ditekan atau di beri gaya) maka sensor akan membaca tekanan yang di alami oleh base.

2. Faktor yang berpengaruh pada pasir.

\section{Daftar Pustaka}

[1] Abdelhameed, Magdy. 2014. VDI 2206. Cairo: Ain Shams University.

[2] Alfatah, Haekal. 2017. Rancang Bangun Mesin Continous Tire Pyrolizer dengan Mekanisme Screw Conveyor Kiln Berkapasitas Input 100 $\mathrm{Kg} / \mathrm{Jam}$. Bandung. POLMAN.

[3] Akbar,Noor Iskandar, 2016, MODIFIKASI DONGKRAK MEKANIK MENJADI 
ELEKTROMEKANIK KAPASITAS 2 TON, Bandung, Universitas Pasundan.

[4] Anas Inzar, Djambiar Riswan, 2008, APLIKASI LABVIEW PADA SISTEM AKUISISI DATA BERBASIS MIKROKONTROLER. Pusat Teknologi Akselerator dan Proses Bahan. Yogyakarta.

[5] Austin, hughes. 1990. Electric Motor and Driver, Elsevier, oxford

[6] https://store.arduino.cc/usa/arduino-mega2560-rev3/2018.

[7] http://sebarinilmu.blogspot.com/2016/03/tutorial-arduinoir-obstacle-sensor.html.

[8] http://www.kitomaindonesia.com/article/201 5/23/load-cell-dan-timbangan.

[9] https://www.dynapar.com/technology/encode r_basics/incremental_encoder/2018

[10] http://www.basrid.co.uk/ridsdale/images/pdf LSTE catalogue 800\%20.pdf

[11] Iskanda, Tengku . Saputra, Hendri Maja. 2017. Perbandingan Average Filter dengan Hanning Filter pada Pengolahan Sinyal Load Cell. Pekanbaru. Politeknik Caltex Riau.

[12]K. Smyksy, J. Zych, T. Snopkiewicz.2015 . ANALYSIS OF MODERN METHODS OF ASSESSING THE QUALITY OF SAND FOUNDRY MOULDS. AGH University of Science and Technology, Faculty of Foundry Engineering, Kraków, Poland

[13] Katalog AVIA SEMICONDUCTOR/HX711

[14] Nawari, Giaz Afriza. 2017. RANCANG BANGUN ALAT UKUR CURAH HUJAN DENGAN KENDALI
MOTOR DC PADA BUCKET BERBASIS BERAT AIR. Bandung .POLMAN.

[15] Pirmansyah, Ardi. 2017. PENGATURAN KECEPATAN MOTOR DC BEBAN VARIABEL PADA MESIN PELUBANG MULSA PLASTIK OTOMATIS. Padang. Politeknik Negeri Padang.

[16] Purwanto, D. 2004. Rancang Bangun Load Cell Sebagai Sensor Gaya pada Sistem Uji. Bandung: BPPT.

[17]SSyukriyadin, SSyahrizal, G Mansur, H P Ramadhan. 2017. Permanent magnet DC motor control by using arduino and motor drive module BTS7960. Banda Aceh. Syiah Kuala University,

[18]Suhendra, Imam . Setyo Pambudi, Wahyu. 2015. APLIKASI LOAD CELL UNTUK OTOMASI PADA DEPOT AIR MINUM ISI ULANG. Batam. Universitas Internasional

[19]Suprianto, Danang. 2013. PENGUKURAN SERTA AKUISISI DATA LOAD DAN DISPLACEMENT ALAT UJ TEKAN PASIR CETAK DENGAN MENGGUNAKAN VISUAL BASIC 6.0. Bandung. POLMAN

[20]Sutiyoko, Lukman Effendi, Muh. 2012. STUDI KASUS KOMPOSISI PASIR CETAK GREENSAND TERHADAP KEKASARAN PERMUKAAN BENDA COR. Klaten. Politeknik Manufaktur Ceper Klaten

[21] VDG-taschenbücher. giesserei--verlag gmbh düsseldorf

[22] www.EngineeringToolBox.com/2018 